P-ISSN: 2541-6960; E-ISSN: 2549-8754

Yupa: Historical Studies Journal

Vol. 4 No. 1, 2020 (9-19)

http://jurnal.fkip.unmul.ac.id/index.php/yupa

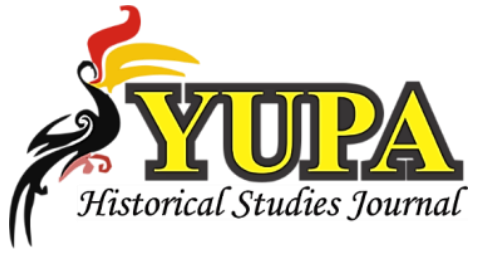

\title{
Pandemi Flu Spanyol di Banjarmasin, Karesidenan Borneo bagian Selatan dan Timur (1918-1920)
}

\author{
Mansyur \\ Universitas Mulawarman, Banjarmasin, Indonesia \\ mansyur_daeng@yahoo.com
}

\begin{tabular}{ccc}
\hline Received & Accepted & Published \\
$03 / 07 / 2020$ & $02 / 09 / 2020$ & $10 / 09 / 2020$ \\
\hline
\end{tabular}

\begin{abstract}
The high of covid 19 cases in Banjarmasin seems to repeat history. The entry of the deadly pandemic virus is actually not new. About a century ago, in 1918-1919, the Spanish flu which shook the world, also hit Banjarmasin, the residency of southern and eastern Borneo. The flu, which the Banjar people called "hot fever", became a pandemic. As many as 1.424 people have fallen victim to influenza. This research method is a research method using heuristics, analysis, interpretation and historiography. Sail out of ships passenger ships that sail and return from Singapore to Banjarmasin, Bawean, and Batavia among them are passengers from SS Camphuys, SS Van Hoorn, SS Van Rees, and SS Senang. Banjar people have used traditional medicines such as ginger. Besides traditional medicine, the people of that era also connected with metaphysical beliefs. Those who suffer from illness are often considered to have violated adat restrictions.
\end{abstract}

Keywords: pandemic, spanish flu, banjarmasin, south Kalimantan.

\begin{abstract}
Abstrak Tingginya kasus covid 19 di Banjarmasin seakan mengulangi sejarah. Pandemi virus mematikan pada kenyataannya bukanlah hal baru. Sekitar satu abad silam, tepatnya pada tahun 1918-1919, flu Spanyol yang mengguncang dunia melanda Banjarmasin. Pada saai itu, Banjarmasin berstatus sebagai ibukota Karesidenan Borneo bagian selatan dan timur. Flu tersebut dinamakan "demam panas" oleh masyarakat Banjar. Sebanyak 1.424 orang tercatat menjadi korban penyakit influenza. Penelitian ini menggunakan metode sejarah, yang terdiri dari tahapan heurisik, kritik, interpretasi dan historiografi. Hasil penelitian menunjukkan bahwa Pandemi flu spanyol di Banjarmasin dan sekitarnya diduga berasal dari para penumpang kapal laut yang berlayar dan pulang dari Singapura ke Banjarmasin, Bawean, dan Batavia, seperti kapal S. S. Camphuys, S. S. Van Hoorn, S. S. Van Rees, dan S. S. Senang. Masyarakat Banjar telah menggunakan obat-obat tradisional untk melawan pandemi ini sebelum obat medi ditemukan, seperti temulawak. Di samping pengobatan tradisional, masyarakat mempercayai hubungan pandemi dengan hal-hal metafisik. Mereka percaya bahwa penderita telah melanggar pantangan adat.
\end{abstract}

Kata kunci: pandemi, flu spanyol, banjarmasin, kalimantan selatan. 


\section{PENDAHULUAN}

Sekitar beberapa bulan terakhir (Januari-Juni 2020), penyebaran kasus virus corona terus meluas ke berbagai negara di seluruh dunia. Dari data tirto.id, penambahan kasus infeksi virus corona di dunia masih terus terjadi dengan jumlah signifikan. Lebih dari 100 ribu pasien perhari. Pada 24 Juni 2020, total kasus positif di dunia tercatat meningkat menjadi 9.273.773 orang. Data tersebut merupakan update terbaru dari CSSE Johns Hopkins University. Angka kematian pasien Covid-19 juga belum berhenti, hingga mencapai jumlah 477.807 jiwa. Kematian tertinggi berasal dari Amerika Serikat, Brasil dan Inggris.

Meski demikian, lebih dari separuh pasien positif corona di dunia saat ini telah dinyatakan sembuh mencapai 4.645 .628 orang. Memang secara umum sekitar 76 negara di seluruh dunia yang mengonfirmasi terinfeksi virus corona. Namun, secercah harapan muncul melihat jumlah pasien sembuh dari virus corona mengalami peningkatan yang cukup signifikan. Di wilayah China, lebih dari 50 persen pasien dinyatakan berhasil sembuh.

Sementara itu di Indonesia, pemerintah mengumumkan tambahan pasien positif virus corona Covid-19. Data dari wartakota.tribunnews.com., jumlah pasien Virus Corona (COVID-19) di Indonesia bertambah 1.113 orang, per Rabu 24 Juni 2020. Total ada 49.009 kasus positif. Sementara, jumlah pasien sembuh bertambah 417 orang, sehingga total pasien sembuh ada 19.658 orang. Sementara pasien yang meninggal bertambah 38 orang, sehingga total ada 2.573 pasien Covid-19 yang meninggal dunia.

Wajar jika "Kegemparan" karena virus corona juga melanda Banjarmasin, Kalimantan Selatan. Dari update kanalkalimantan.com tanggal 18 Juni 2020 terdata 2.326 Kasus Covid-19 di Kalsel, hampir separuh berasal dari Banjarmasin. Lonjakan kasus positif Covid-19 di Kalimantan Selatan terus terjadi. Dari jumlah ini, tercatat pasien yang meninggal sebanyak 150 orang. Semua pihak pun siaga menanggulangi makin melinjaknya angka penderita virus mematikan ini ke banua.

Kasus ini seakan menjadi sejarah yang berulang. Masuknya pandemi virus mematikan sebenarnya bukan hal baru melanda wilayah Banjarmasin dan sekitarnya. Tepat satu abad silam, tepatnya pada tahun 1918-1919, flu Spanyol mengguncang dunia dan berhasil masuk ke wilayah Karesidenan Borneo bagian selatan dan timur. Flu yang oleh masyarakat Banjar dinamakan "demam panas" ini telah menjangkiti ribuan warga di Banjarmasin.

Pada wilayah lain penyakit ini mendapat sebutan "Penjakit Aneh", "Penjakit Rahasia", dan "Pilek Spanje" Sebagai perbandingan awal, data saat itu Flu Spanyol membunuh sekitar dua sampai 20 persen penderita yang terinfeksi. Menurut www.historia.com., persentase tersebut tentunya jauh lebih besar dibandingkan influenza 
biasa yang hanya membunuh 0,1 persen dari total penderita. Dahsyatnya serangan wabah tersebut membuat virologis dari Amerika Serikat, Jeffery Taubenberger menyematkan gelar kepada Flu Spanyol sebagai "The Mother of All Pandemics"

Melansir data www.historia.com, menurut John Barry diperkirakan jumlah korban tewas mencapai 21 juta jiwa, sedangkan menurut Nial Johnson dan Juergen Mueller mencapai 50-100 juta jiwa. Angka kematian terbesar terjadi pada balita, orang berumur 2040 tahun, dan orang berumur 70-74 tahun. Dengan demikian, selama Maret 1918 sampai September 1919, Flu Spanyol telah merenggut kurang lebih dua persen populasi dunia yang berjumlah sekitar 1,7 miliar orang. Angka yang jauh melebihi korban Perang Dunia I sekitar 9,2 juta-15,9 juta jiwa. Tahun 1918 merupakan tahun genting dalam sejarah umat manusia. Pandemi ini terjadi secara global. Seiring dengan babak pamungkas dari Perang Dunia I pada tahun tersebut, umat manusia diuji pula dengan pandemi flu ganas, Flu Spanyol.

\section{METODE}

Metode penelitian ini adalah metode penelitian sejarah. Mengumpulkan sumbersumber lisan, sumber sumber tertulis maupun sumber benda peninggalan masa lampau dengan tahap heuristik, kritik, interpretasi dan historiografi. Sumber tertulis yang digunakan dalam penulisan artikel ini adalah sumber sekunder, yaitu melalui literatur yang relevan dengan penelitian, seperti buku-buku sejarah, laporan penelitian, skripsi, dan internet. Sumber data ini didapat dari Perpustakaan dan Arsip Daerah Provinsi Kalimantan Selatan, Arsip Nasional Republik Indonesia (ANRI) dan Perpustakaan Nasional Republik Indonesia. Umumnya data dari perpustakaan berupa sumber sekunder merupakan hasil penelitian atau penulisan ulang sumber pertama.

\section{HASIL DAN PEMBAHASAN}

\section{Flu Spanyol di Banjarmasin, 1.424 Warga Menjadi Korban}

Menurut Dewi (2013), Flu spanyol disebabkan oleh virus influenza tipe A dengan subtipe H1N1. Diperkirakan Flu Spanyol menjadi virus influenza terganas dalam sejarah kesehatan. Di Hindia Belanda, penyebaran Flu Spanyol terjadi dalam dua gelombang. Pertama, pada Juli 1918-September 1918. Meskipun di beberapa tempat, seperti Pangkatan (Sumatera Utara) sudah menyebar pada Juni 1918 yang diduga kuat ditularkan penumpang kapal laut dari Singapura. Sementara itu, kawasan timur, seperti Borneo (Kalimantan), Sulawesi dan Maluku, masih terbebas dari Flu Spanyol selama gelombang pertama. Gelombang kedua Flu Spanyol terjadi pada Oktober-Desember 1918. Meskipun di beberapa tempat berlangsung sampai akhir Januari 1919, , terutama di kawasan timur. Menurut 
Wibowo (2009), para penguasa di beberapa tempat telah melaporkan adanya adanya kenaikan jumlah pasien influenza dengan jumlah yang sangat mengejutkan.

Pada gelombang pandemi kedua tahun 1918, Banjarmasin menjadi lokasi pertama yang melaporkan kemunculan influenza. Kasus tersebut dilaporkan terjadi pertama kali di Pelabuhan Banjarmasin, Makassar, dan Buleleng di Pulau Bali. Menurut Wibowo (2009) di beberapa tempat telah menunjukkan kenyataan adanya influenza sebagai penyakit baru yang melanda daerah tersebut. Sementara itu, lokasi lainnya menunjukkan bahwa penyakit flu telah melanda beberapa daerah beberapa bulan sebelumnya. Para pejabat melapor kepada pemerintah di Batavia menggunakan TZG (Telegram van zeer geheim). Biasanya telegram ini digunakan oleh para birokrat Belanda untuk menunjukkan kondisi darurat dan mendesak.

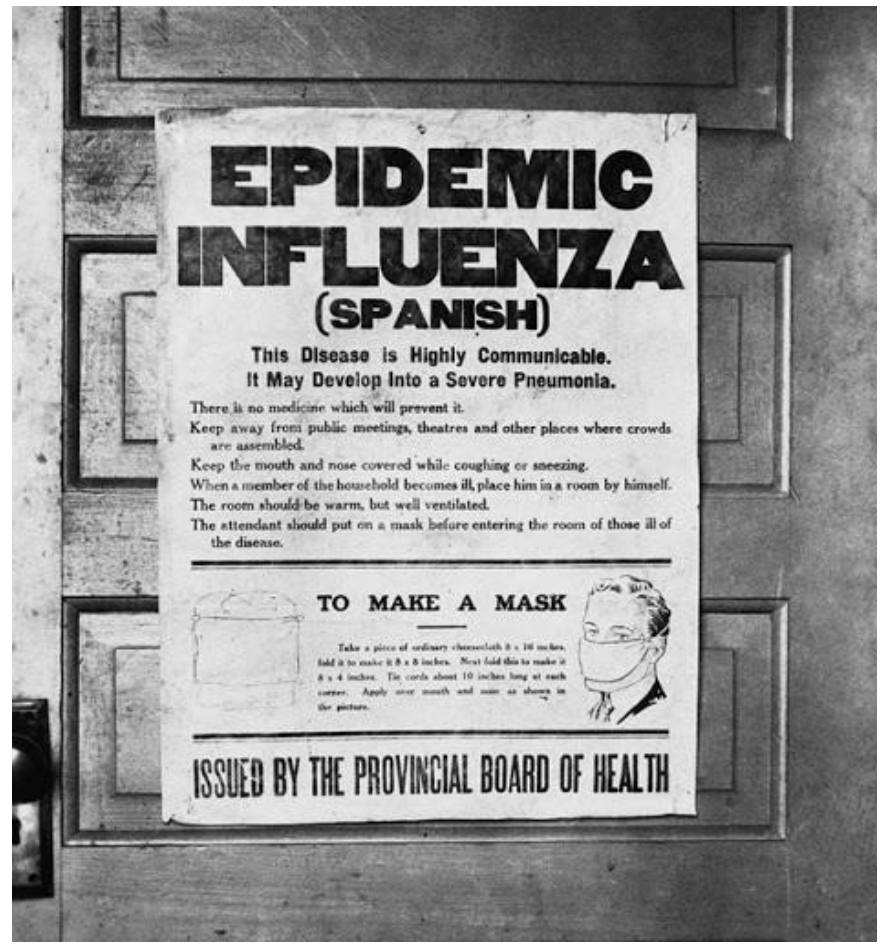

Gambar 1. Pengumuman tentang epidemi Flu Spanyol di Eropa tahun 1918.

Sumber: bayobserver.ca

Pada awal November 1918, Residen Borneo bagian Selatan dan Timur yang berkedudukan di Banjarmasin C.A. Kroesen (1898-1924), telah mengirimkan telegram darurat yang isinya menyatakan bahwa daerahnya telah terserang wabah influenza. Munculnya Flu Spanyol do Banjarmasin diduga berasal daripara penumpang kapal laut yang berlayar mulai dari Hongkong, kemudian transit di Pelabuhan Singapura. Selanjutnya kapal tersebut berlayar kembali menuju pelabuhan pelabuhan di Hindia Belanda. Satu diantara pelabuhan tujuannya adalah Pelabuhan Banjarmasin. 
Wajar, pada era itu Banjarmasin menjadi satu satunya pelabuhan terbaik di pantai timur dan selatan Pulau Kalimantan. Berbeda dengan pelabuhan-pelabuhan di wilayah lain yang pada umumnya terletak di tepi laut. Pelabuhan Banjarmasin terletak di antara dua sungai besar, yaitu Sungai Martapura dan Sungai Barito. Kedua sungai ini merupakan urat nadi perekonomian daerah Banjarmasin maupun sekitarnya yang menjadi posisinya sebagai penyangga atau hinterland. Banjarmasin dapat dilayari oleh kapal-kapal besar sehingga Kota Banjarmasin dapat dijangkau oleh kapal-kapal samudera. Pada wilayah Kota Banjarmasin inilah terletak Pelabuhan Banjarmasin yang dikenal juga sebagai Dermaga Martapura atau Pelabuhan Martapura (Susilowati, 2004).

Dewi (2013) menyebutkan bahwa dalam telegram darurat Residen Banjarmasin November 1918 dinyatakan bahwa keadaan di Banjarmasin sedang kacau. Hal ini diperkuat dengan laporan inspektur kesehatan yang menyatakan adanya peningkatan kematian yang tinggi yang umumnya disebabkan oleh penyakit Flu Spanyol. Sebanyak 1.424 orang di daerah Borneo bagian Selatan dan Timur, telah tercatat menjadi korban penyakit influenza.

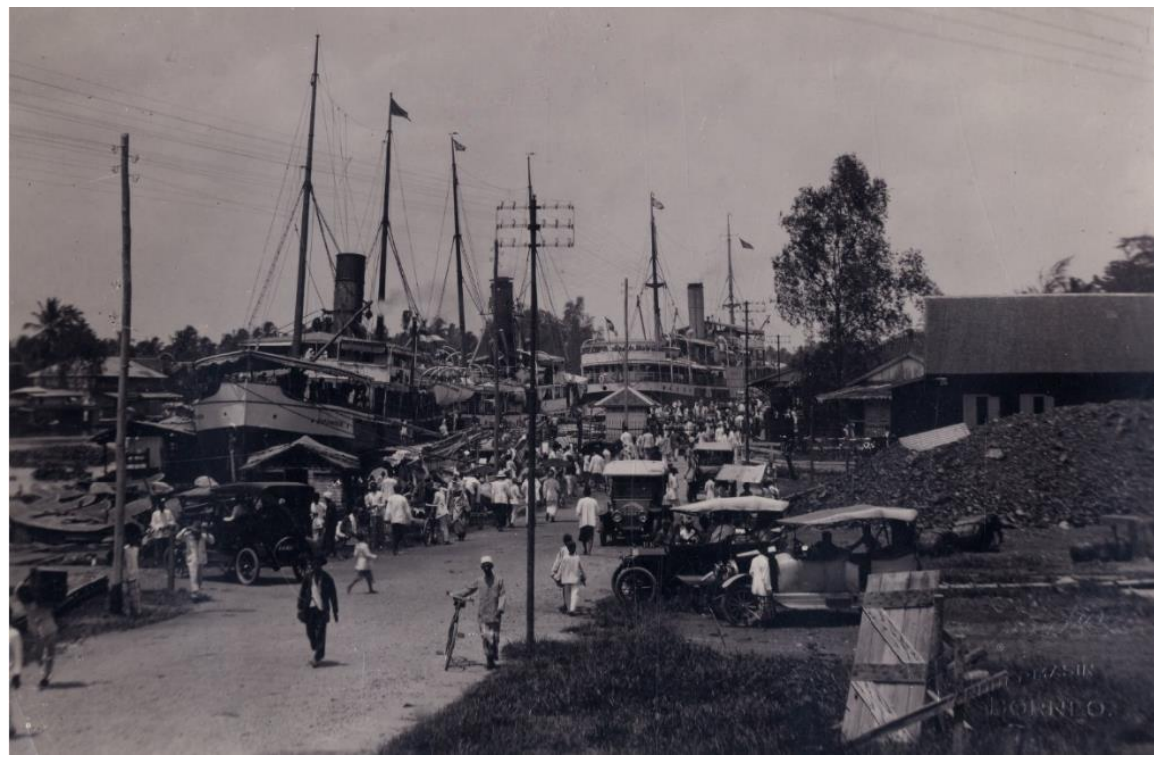

Gambar 2. Pelabuhan Banjarmasin Tahun 1930-an, Sumber: KITLV.

Kasus Flu Spanyol di Banjarmasin diduga ditularkan dari para penumpang kapal yang melakukan pelayaran dan pulang dari Singapura ke Bandjarmasin, Bawean, dan Batavia. Diantaranya para penumpang dari kapal S. S. Camphuys, S. S. Van Hoorn, S. S. Van Rees, dan S. S. Senang (Nurenee, 2011). Oleh karena itu, Pemerintah Hindia Belanda berupaya melakukan upaya pencegahan. Hal ini dikarenakan, banyak kapal dari Hongkong yang merapat di pelabuhan wilayah Hindia Belanda seperti Pelabuhan Banjarmasin untuk menurunkan penupang. Pengawasan difokuskan terhadap kapal-kapal yang datang dari Hongkong dan telah transit di Singapura menuju Banjarmasin. 


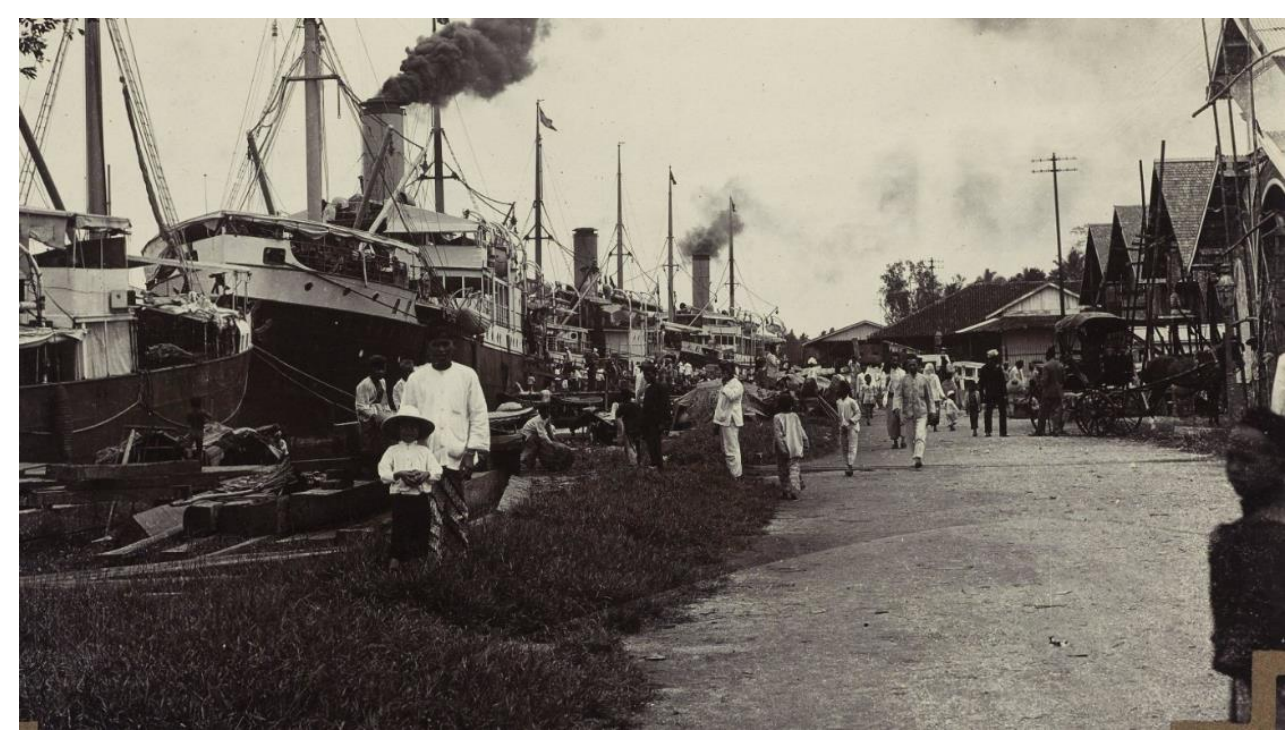

Gambar 3. Pelabuhan Banjarmasin Tahun 1935-an

Sumber: KITLV.

Sementara itu dalam skala besar, Priyanto Wibowo (2009) juga mengungkapkan dalam waktu singkat, yaitu sekitar satu minggu, penyakit ini mulai menyebar ke Jawa Timur. Surabaya, sebagai kota pelabuhan utama, juga diserang wabah influenza dan menjadi pintu penyebaran masuk hingga ke daerah sekitarnya. Pada akhir November 1918, Pemerintah Hindia Belanda menerima laporan bahwa penyakit itu telah melanda Jawa Tengah dan sudah memasuki wilayah Jawa Barat.

\section{Pengobatan Tradisional dan Tablet Campuran Aspirin}

Pandemi Flu Spanyol yang melanda Banjarmasin, seabad lalu tepatnya tahun 19181920 memang menjadi wabah mematikan di Kota Seribu Sungai. Walaupun demikian, pandemi ini sebenarnya sudah melanda Banjarmasin dalam skala kecil tahun 1890. Pada 5 April 1890, Laboratorium voor Pathologische Anatomie en Bacteriologie melaporkan hasil observasi di Borneo bahwa influenza telah melanda Bandjermasin untuk kali pertama. Kemudian, disusul dengan kota utama di sekitarnya, hingga daerah yang jauh dari perkotaan.

Pada awal April 1890, pada saat hampir bersamaan influenza mulai menjadi epidemi di Pantai Barat Sumatra, di wilayah Borneo bagian Selatan dan Barat. Hal ini dilansir oleh Departement van Zaken Oversee, dua tahun kemudian, tepatnya pada tahun 1892. Penyakit influenza (spanish griep/flu spanyol) kembali melanda wilayah Bandjermasin dan Stagèn (Poeloe Laoet) 26 tahun kemudian. Wabah ini langsung menyebar dari penumpang kapal yang mendarat di Pelabuhan Banjarmasin dan Stagen dari Singapura pada pertengahan Juli. 
Pada bulan Juli beberapa pusat kesehatan di Banjarmasin melaporkan maraknya wabah ini. Demikian dituliskan Dienst der volksgezondheid, pada tahun 1920. Hal sama dituliskan Eisenberger (1936). Pada tahun 1918, Borneo menjadi terkenal di seluruh wilayah karena menjadi episentrum penyakit kolera dan flu Spanyol. Penyakit ini telah menjangkiti dari populasi/penduduk di wilayah Borneo hingga 90 persen

Berdasarkan hasil penelitian Laboratorium voor Pathologische Anatomie en Bacteriologie di Banjarmasin menemukan basil influenza pada kedua kasus ini menunjukkan kesamaan antara kasus influenza tahun 1890 dan tahun 1918-1920. Hingga tahun 1925 kemudian, Verslag der handelingen der Staten-Generaal mencatat terdapat sisa sisa penyakit influenza sampai ke pelosok wilayah-wilayah Dayak dari daerah Samarinda, Bandjermasin hingga subdivisi Puruktjahoe dari daerah Doesoenlanden.

Pada awal November 1918, Residen yang berkedudukan di Banjarmasin mengirimkan telegram darurat. Pesan tersebut menyatakan bahwa daerahnya terserang wabah. Hal ini didukung, inspektur kesehatan yang melaporkan adanya peningkatan kematian yang tinggi. Kematian tersebut umumnya disebabkan oleh penyakit Spanyol/Spanis Griep atau Flu Spanyol. Dalam telegram tersebut, dilaporkan sebanyak 1.424 orang di daerahnya telah tercatat menjadi korban penyakit influenza. Besarnya jumlah korban jiwa di Banjarmasin khususnya, menandakan kegagalan pemerintah dalam menghadang penyebaran virus melalui pelabuhan. Pada akhirnya otoritas di Batavia memang dapat mencegah penyebaran wabah penyakit. Akan tetapi, tentunya tidak dapat diterapkan hal yang sama di kota-kota pelabuhan lainnya.

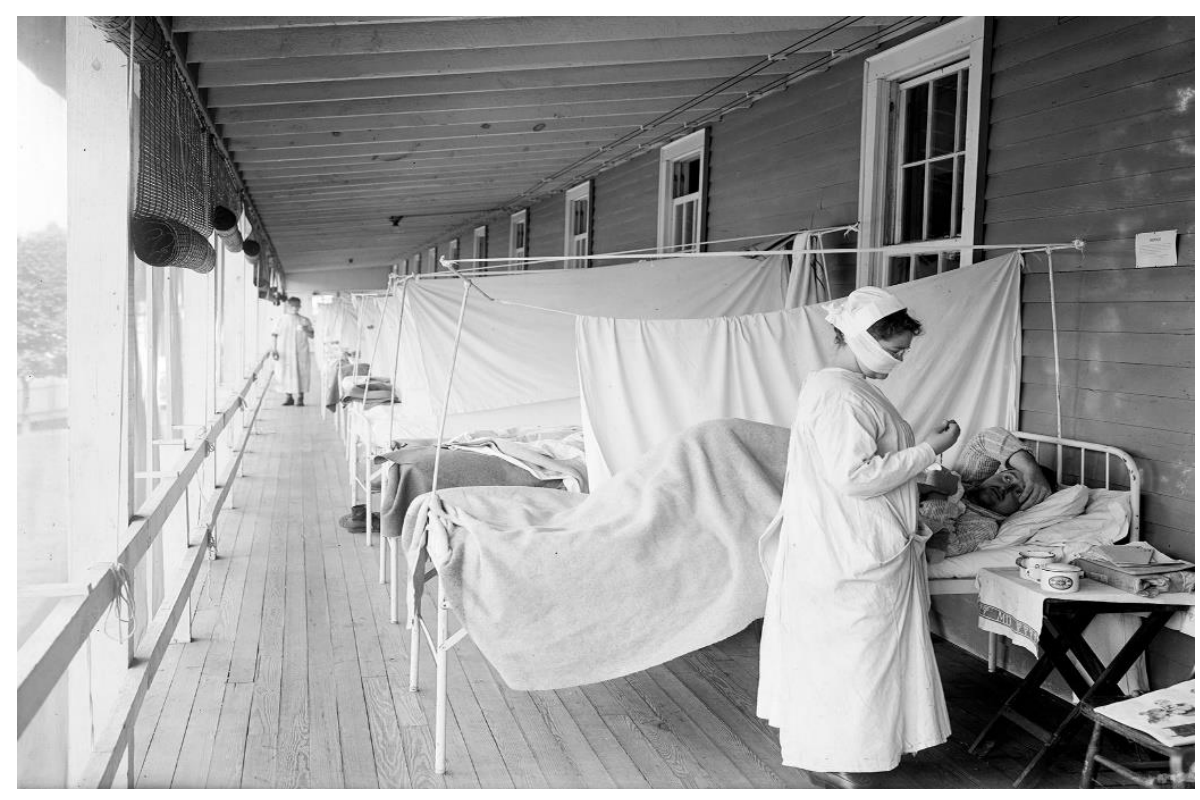

Gambar 4. Pengobatan Flu Spanyol di Eropa. 
Sumber: www.deccanherald.com.

Bagaimana upaya pencegahan dan pengobatan flu spanyol di Banjarmasin? Tidak terdapat catatan khusus mengenai penanggulangannya di wilayah Borneo. Tetapi secara umum, terdapat satu ulusan menarik dari Rukmantara (nd.) dalam tulisannya tentang When Sneeze Kills: Indonesia's Influenza Pandemic of 1918. Ia menuliskan bahwa masyarakat telah melakukan upaya pengobatan menggunakan obat tradisional seperti temulawak, sebelum obat medis ditemukan. Hal ini didasarkan kepercayaan bahwa jamu dapat menghangatkan tubuh dan mengobati influenza.

Di samping pengobatan tradisional, menurut Priyanto (2009) masyarakat masa itu juga menghubungkan dengan kepercayaan metafisik. Panderita dianggap telah melanggar pantangan adat. Menurut mereka, langkah yang perlu diambil adalah dengan mendatangi makam-makam suci di tempat terjadinya wabah dan melaksanakan ritual adat sebagai upaya untuk memulihkan keadaan. Selain itu, ada juga yang meyakini bahwa penyakit tersebut disebabkan oleh gangguan hantu penunggu lokasi tertentu.

Pada sisi lain, Kepala Dinas Kesehatan Sipil membentuk sebuah komite yang bertugas menyelidiki asal mula penyakit ini, penyebaran, dan pengobatannya (Mededeelingen van den Burgerlijken Geneeskundigen Dienst in Nederlandsch-Indie, 1920). Namun karena luasnya wilayah Hindia Belanda, akhirnya komite ini pun tidak dapat melaksanakan tugasnya dalam waktu cepat. Hal ni megakiobatkan korban terus berjatuhan.

Demikian halnya diungkapkan Dewi (2013), saat pemerintah Hindia-Belanda masih bingung untuk menangani penyakit ini, lembaga Nederlandsch Zending Genootschap berinisiatif menanggulangi penyakit yang dinamakan masyarakat dengan sebutan "demam panas", "Penjakit Aneh", "Penjakit Rahasia", dan "Pilek Spanje”. Memanfaatkan fasilitas rumah sakit yang seadanya, para ahli kesehatan zending berupaya untuk mencegah tersebarnya wabah dan berusaha mengobati para pasien yang telah terjangkit. Dalam rangka mencegah penyebaran penyakit tersebut, para pendeta dan dokter zending juga aktif menyebarkan informasi mengenai gejala dan penanganan penyakit ini. 


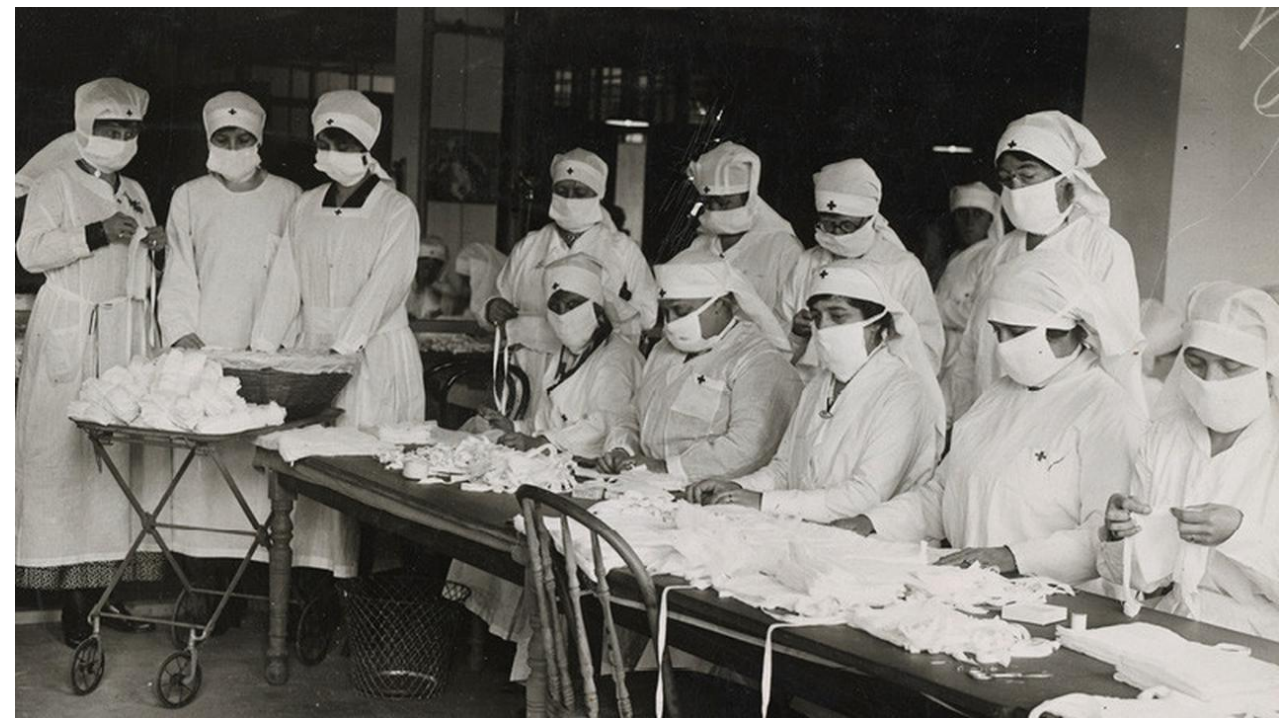

Gambar 5. Perawat menyiapkan masker untuk mencegah penyebaran flu Spanyol pada 1918. Sumber foto: National Archives.

Pada bulan November 1918, dibentuk sebuah tim yang memiliki wewenang dalam mengambil tindakan darurat untuk menghadapi wabah influenza. Dokter de Vogel sebagai pimpinan tim khusus influenza membuat sebuah inisiatif. Ia mengajukan perlunya peraturan yang berskala nasional yang bertujuan untuk membasmi penyakit influenza. Peraturan ini tentunya diharapkan dapat menjadi acuan dalam pengambilan kebijakan oleh pemerintah daerah di berbagai wilayah di Hindia Belanda (Priyanto, 2009).

Dengan demikian, pada awal tahun 1919, rancangan undang-undang influenza (Inflenza Ordonantie) telah dibuat dan diedarkan kepada pihak-pihak yang terkait. Peraturan karantina menjadi landasan dalam membuat Staadblad tahun 1911 nomor 277 ini. Pada 20 Oktober 1920, peraturan tersebut ditetapkan. Kemudian, di seluruh wilayah Hindia Belanda peraturan tersebut diberlakukan dan dimuat dalam Lembaran Negara Hindia Belanda (Staatsblad van Nederlandsch Indie nomor 723 tahun 1920).

Berita menggembirakan mulai muncul ketika Mededeelingen van den Burgerlijken Geneeskundigen Dienst in Nederlandsch-Indie (1922) melaporkan bahwa pada tahun 1919, laboratorium kedokteran di Batavia telah berhasil menemukan obat untuk menyembuhkan pasien influenza. Obat influenza ini dibuat dalam bentuk tablet. Komposisi tablet ini adalah 0,250 aspirin, 0,150 pulvis doveri dan 0,100 camphora. Dinas kesehatan rakyat dalam masa produksi pertamanya menghasilkan hampir 100 ribu butir (M: 101). Hasil produksi kemudian didistribusikan secara gratis kepada masyarakat. Penyediaan tablet tersebut tentunya sangat membantu mengobati pasien influenza. Bahkan, masker pun dibagikan secara cuma-cuma untuk mencegah meluasnya virus. 


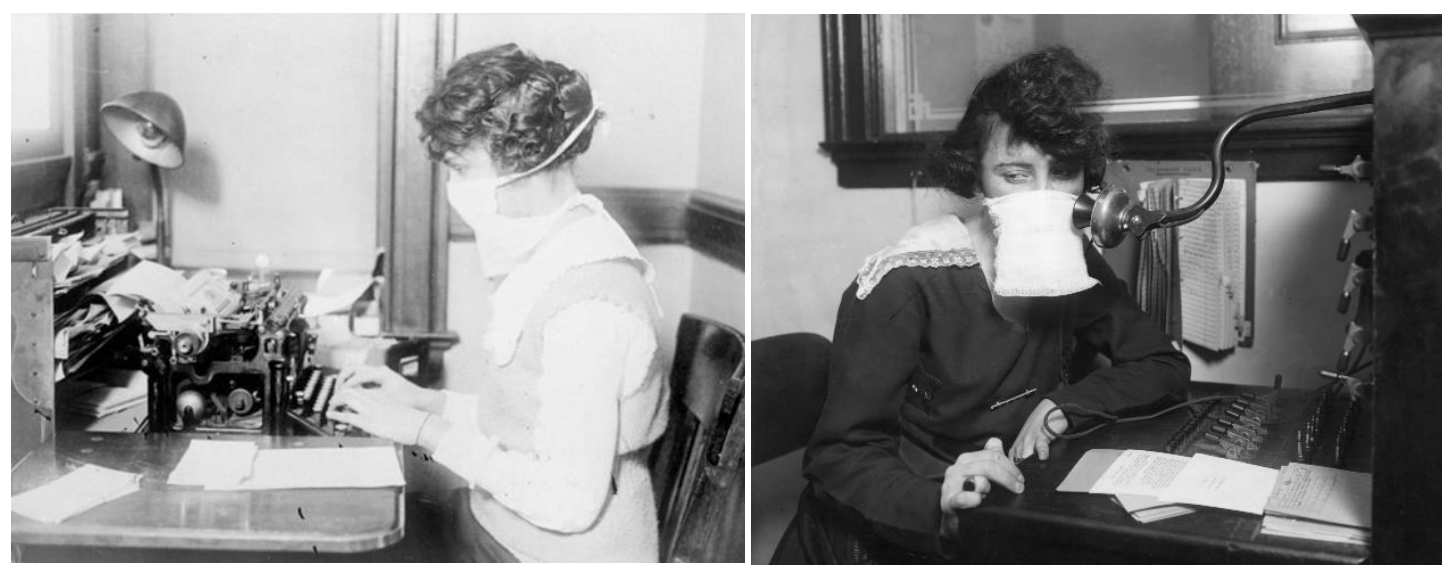

Gambar 6. Seorang juru ketik dan operator telepon yang mengenakan masker flu pada Oktober 1918.

Sumber: untappedcities.com. \& medium.com

Priyanto (2009) memaparkan bahwa dalam rangka memudahkan penyebaran informasi, pemerintah kolonial melalui Balai Pustaka menerbitkan sebuah buku pedoman mengenai penyakit influenza yang berjudul Lelara Influenza dalam Bahasa Jawa dan ditulis dalam Huruf Jawa. Buku ini berisi percakapan di antara tokoh-tokoh wayang (punakawan). Tokoh ini dipilih untuk menyampaikan pesan-pesan kesehatan karena telah populer dikenal oleh masyarakat

Upaya mengatasi flu Spanyol lumayan berhasil menanggulangi flu spanyol di wilayah Banjarmasin dan sekitarnya. Departement van Zaken Oversee (1920), berdasarkan laporannya menuliskan Flu Spanyol yang merebak sejak 1918 masih terasa sampai bulanbulan pertama 1919, tetapi itu tidak lagi mengakibatkan banyak korban. Hanya ada beberapa kasus kolera yang terjadi di wilayah Hulu Sungai dan Banjarmasin.

\section{KESIMPULAN}

Kondisi saat ini di tengah merebaknya pandemi covid 19 seolah-olah merupakan refleksi yang terjadi di masa lalu. Seratus tahun lampau. Philip Guedalla (1889-1944) sejarawan dan esais, pop kultur asal Inggris, mengatakan l'histoire se répète, yang berarti sejarah akan berulang. Sama dengan ungkapan sejarawan kelahiran Maida Vale, London "sejarah berulang dengan sendirinya. Sejarah saling mengulang satu sama lain." Hal ini menginspirasi Keny Arkana, seorang rapper Perancis keturunan Argentina menggubah lagu bertitel l'histoire se répète.

Apakah sejarah itu berulang? memang tidak, sejarah tidak akan mungkin berulang. Yang berulang adalah dan hanyalah kegagalan manusia belajar dari sejarah. Sudah sepatutnya belajar dari sejarah ketika 1.424 orang di daerah Borneo bagian Selatan dan Timur, telah tercatat menjadi korban penyakit influenza. Belajar bagaimana 
penanggulangan pandemi ini, keberhasilan dan kegagalannya. Muaranya, bisa belajar dari sejarah untuk menanggulangi pandemi covid 19 yang merebak di era kekinian.

\section{REFERENSI}

Addi, M. Idhom, "Update Corona di Dunia Hari Ini 24 Juni 2020 \& Data Korban Terkini", https://tirto.id/update-corona-di-dunia-hari-ini-24-juni-2020-data-korbanterkini-fK54

Departement van Zaken Oversee. (1892). Verslag van bestuur en staat van NederlandschIndie, Suriname en Curacao. Netherlands : Departement van Zaken Oversee.

Dewi, Nofita Rusdiana. (2013). “Wabah Influenza di Jawa Tahun 1918-1920”. Jurnal Avatara, e-Journal Pendidikan Sejarah Volume1, No 2, Mei.

Dienst der volksgezondheid. (1920). MededeelIngen van den Dienst der Volksgezondheid in Nederlandsch-Indie. Dutch East Indies : Dienst der volksgezondheid.

ederlandsch-Indië, Volume 46, 1906

Fikri, "Catat 2.326 Kasus Covid-19 di Kalsel, Hampir Separuh Berasal dari Banjarmasin", dalam https://kanalkalimantan.com/catat-2-326-kasus-covid-19-di-kalselhampir-separuh-berasal-dari-banjarmasin/

Nurenee, Lee. (2011). "A Plague O' Both Your Houses: Medicine, Power, and the Great Flu of 1918-1919 In Britain And Singapore". A Thesis Submitted for the Degree of Master of Arts Department of History National University of Singapore.

Rafando Lie, "Seabad Flu Spanyol", dalam https://historia.id/sains/articles/seabad-fluspanyol-DBKbm

Rukmantara, Arie (2009). "When Sneeze Kills: Indonesia's Influenza Pandemic of 1918" Executive Summary Seminar Pandemi Influenza 1918 Di Hindia Belanda, 15 Oktober 2009 di Kampus UI, Depok yang diselenggarakan Departemen Sejarah Fakultas Ilmu Pengetahuan Budaya Universitas Indonesia Kampus Universitas Indonesia.

Staten-Generaal. (1925). Verslag der Handelingen der Staten-Generaal. Bagian 2. Netherlands : Staten-Generaal. Eerste Kamer.

Susilowati, Endang. (2004). "Pasang Surut Pelayaran Perahu Rakyat di Pelabuhan Banjarmasin, 1880-1990". Disertasi dalam bidang Ilmu Pengetahuan Budaya Program Studi Ilmu Sejarah, Universitas Indonesia.

Wibowo, Priyanto dkk. (2009), Yang Terlupakan: Pandemi Influenza 1918 di HindiaBelanda, Jakarta: kerjasama antara Departemen Sejarah Fakultas Ilmu Pengetahuan Budaya Universitas Indonesia, Unicef Jakarta \& Komnas FBPI.

Yaspen Martinus, "Update Kasus Covid-19 di Indonesia 24 Juni 2020: Bertambah 1.113, Pasien Positif Jadi 49.009 Orang", dalam https://wartakota.tribunnews. com/2020/06/24/update-kasus-covid-19-di-indonesia-24-juni-2020-bertambah1113-pasien-positif-jadi-49009-orang. 